\title{
Arts majors and the Great Recession: a cross-sectional analysis of educational choices and employment outcomes
}

\author{
Richard J. Paulsen ${ }^{1}$ (D)
}

Received: 9 January 2021 / Accepted: 30 August 2021 / Published online: 8 September 2021 (c) The Author(s), under exclusive licence to Springer Science+Business Media, LLC, part of Springer Nature 2021

\begin{abstract}
This study uses American Community Survey data to examine the impact of the Great Recession on college graduates majoring in the arts. Arts graduates play important roles in an economy, through both artistic creation and in careers outside of the arts. While the Great Recession took a significant toll on the US economy generally, arts majors faced additional vulnerabilities as industries that rely on discretionary spending, like the arts and entertainment, are especially hard hit in times of economic downturn. This paper assesses the impact of graduating during or shortly after the recession relative to graduating shortly before this period on educational choices, including choice of major, double majoring, and completing an advanced degree, and career outcomes, including employment status, type of employment, hours worked, and earnings, for college graduates majoring in the arts. Graduating before or after the recession is found to have a negative impact on the share of graduates majoring in traditional arts fields, but a positive impact on the share majoring in related creative fields. Using a difference-in-difference estimation strategy, relative to non-art college graduates, traditional arts majors graduating during or after the Great Recession are more likely to complete a double major, be self-employed, be unemployed, work longer hours, and earn less income than those graduating prior to the recession. These impacts are likely to have a negative effect on the pipeline of college-educated artists working in the arts into the future.
\end{abstract}

Keywords Arts · Arts majors · Recession · Great Recession · Creative class · American Community Survey

JEL Classification $\mathrm{E} 32 \cdot \mathrm{J} 24 \cdot \mathrm{Z} 11$

Richard J. Paulsen

Rpaulsen@bloomu.edu

1 Department of Economics, Bloomsburg University of Pennsylvania, Sutliff Hall Suite 220, Room 228, 400 E. 2nd Street, Bloomsburg, PA 17815, USA 


\section{Introduction}

The Great Recession was a time of significant economic hardship for many Americans. Officially, the Great Recession began in December of 2007 and ended in June of 2009, but the negative impact on employment lasted much longer. During this period, the unemployment rate increased from a pre-recession level of about $5 \%$ to a peak of $10 \%$, with rates growing far higher for disadvantaged groups, young adults, and those with lower levels of education (Cunningham, 2018). While economic downturns have a negative impact across the board, those industries that rely on discretionary consumer spending, like the arts and entertainment, are especially likely to suffer. Arts organizations and funding for the arts took significant hits during the Great Recession. Many arts organizations closed, saw endowment losses, or saw budget cuts during this period. Adult attendance of the performing arts fell. Adults and children were less likely to go to the movies and attend live performances (Miringoff \& Opdycke, 2010). Perceptions of the value of arts education and funding for arts education also took a hit during this period (Ramos \& Baugher, 2013).

As the arts suffered during the Great Recession, it is natural to wonder how the labor market and educational attainment in the arts were affected. During this time artists were disproportionately unemployed or underemployed relative to other types of workers. Further, many artists switched to non-arts occupations or pursued selfemployment (Woronkowicz, 2015). One group of workers likely to pursue work in the arts are college graduates with degrees in the arts. While studies have looked at the employment experiences of artists during this time, the labor market and educational experiences of art majors directly have not been explored.

This study will look at the impact of the Great Recession on art majors. ${ }^{1}$ Specifically, this study will explore how the Great Recession impacted the educational decisions of arts majors and their long-term employment outcomes in the USA. Educational decisions explored include the decision to major in an arts field, the decision to double major, and the decision to pursue an advanced degree. Parental approval is an important determinant of major choice, and economic conditions may impact which majors earn parental approval (Zafar, 2012). As employers demand greater skills of workers during economic downturns, students may take steps to increase their human capital (Modestino et al., 2020). Employment-related outcomes considered include employment status, earnings, hours worked, and job type. These outcomes mirror the employment outcomes of Woronkowicz (2015) which focused on the impact of the Great Recession on the employment of artists.

Overall, this study finds notable impacts of graduating during or following the Great Recession on the educational choices and career outcomes of art majors relative to non-art college graduates. Relative to those who graduated shortly prior to

\footnotetext{
1 There is significant heterogeneity in the US education system and notably within arts education. Some college graduates with majors in the arts attend colleges focused exclusively on the arts, while others attend more comprehensive universities and colleges offering a variety of majors. Arts colleges tend to be less selective on academic criteria like test scores, but often require a portfolio (Grant 2017). For nonarts colleges, more selective institutions may have differing admissions criteria by intended major, but the majority of college graduates in the USA are enrolled at less selective institutions.
} 
the Great Recession, those who graduate during or shortly after were less likely to major in a traditional art field, like music or performing arts, though more likely to major in a related creative field, like art education or literature. Graduating during or shortly after the recession had a positive impact on double majoring and a negative impact on completing advanced degrees for those majoring in traditional arts or related creative fields, though the opposite effect was observed for architecture majors. With regard to career outcomes, art majors who graduated during the Great Recession are more likely to be self-employed and have lower earnings conditional on being employed despite working significantly longer hours. For architecture majors, graduating during or after the recession is found to have a positive impact on earnings, though this is likely attributable to an increased likelihood of completing an advanced degree. Art majors who graduated during the recession are significantly more likely to be working in the arts, in occupations like actor or musician, than those who graduated before the recession, but this may be attributable to the increased likelihood of self-employment.

Before proceeding, it is important to call attention to the contributions of this work. First, while other works have focused on the employment impacts of the Great Recession on the employment of artists, this work focuses specifically on college graduates with major fields of study in the arts. While there is some overlap between these groups, that overlap is small. Only about a quarter of traditional arts majors within the sample used for this analysis work directly in an arts occupation. Among those working as artists, only a small share has completed education relevant to working in their field (Bille \& Jensen, 2018). Second, while other works have focused on employment-related outcomes, this work also looks at the impact on educational outcomes for art majors. Beyond playing a role in artistic creation, college graduates with majors in the arts play an important role in entrepreneurship and innovation (Paulsen et al., 2021). As entrepreneurship and innovation are important drivers of economic growth, understanding how economic downturns impact the educational choices and employment of arts majors can have important implications for both developed and developing economies. While the Great Recession was a significant economic downturn, it will be far from the last downturn. Already we have seen an economic downturn associated with the COVID-19 pandemic, so insights gained in analyzing the impacts of the Great Recession can be used in informing reactions to future downturns.

\section{Literature}

As this work looks to contribute to four literatures, this review of the literature will introduce the existing works in these areas. First, I discuss literature looking at the labor market for artists. Second, I explore literature assessing the careers of college graduates who majored in the arts. Third, I introduce literature looking at the impact of recessions on college graduates. Last, literature connecting these areas, looking at recessions and the arts, is discussed. 


\subsection{Labor market for artists}

A vast empirical literature highlights a number of ways in which the labor market for artists differs from the labor markets of other workers. Artists have low income relative to other professional workers and average workers generally (Alper \& Wassall, 2006; Throsby, 1986). While a formal education is required in many professional fields, a formal education is not required to be an artist (Baldin \& Bille, 2021) and many studies have found that a formal education has little impact on earnings (Bille \& Jensen, 2018; Throsby, 1996). Beyond having low average incomes, artists differ from much of the rest of the workforce in a variety of other ways. Artists have higher levels of unemployment (Alper \& Wassall, 2006; Menger, 2006), are more likely to work part-time (Alper \& Wassall, 2006; Throsby \& Peteskaya, 2017), are more likely to hold multiple jobs (Alper \& Wassall, 2000; Menger, 2006; Throsby \& Peteskaya, 2017) and are more likely to be self-employed (Alper \& Wassall, 2006; Woronkowicz $\&$ Noonan, 2019). Despite these negative characteristics, there are still many aspiring artists with hopes of successfully entering into the artistic workforce (Alper \& Wassall, 1998).

Beyond the empirical work highlighting differences between the labor market for artists and non-artists, a vast theoretical literature looks to explain these differences. While the backward-bending labor supply curve derived from the tradeoff between consumption and leisure may be an appropriate model for analyzing labor supply in some professions, some workers, like academics and artists, are likely to derive utility from their work beyond the utility generated from increased consumption. The work preference model of Throsby (1994) suggests that artists are "driven by an irresistible desire to create" and will therefore maximize time spent engaged in artistic creation, subject to a constraint of needing some minimal level of income for survival. This may explain the willingness of artists to continue to create and the excess supply in the artistic labor market despite the lower levels of compensation. This theory finds empirical support in the works of Steiner and Schneider (2013) and Bille et al. (2013) which find that artists experience greater levels of job satisfaction than other workers. Another explanation for the differences in artist labor markets compared to other labor markets relates to the earnings of superstars (Adler, 1985; Rosen, 1981) or "winner-take-all markets" (Frank \& Cook, 1995). Significant earnings differentials arise as a select few become superstars and have very large incomes while the rest at the bottom have low incomes. This competition for superstar earnings leads to many entrants in artistic labor markets, and this is exacerbated as individuals tend to overestimate their likelihoods of success.

\subsection{Careers of arts majors}

Beyond the literature looking at the labor markets for artists, a number of studies have looked at labor market outcomes of college graduates who majored in arts fields. Many authors have used the Strategic National Arts Alumni Project (SNAAP) survey to assess the career outcomes of arts graduates in the USA. With this dataset, the most common questions explored look to identify whether arts graduates are in 
fact working in the arts (Lindemann et al., 2012), why or why not (Frenette \& Dowd, 2018; Lena et al., 2014), and if not, what those graduates are doing instead (Gerber \& Childress, 2017; Lindemann et al., 2012). Lindemann et al. (2012) find that over $50 \%$ of respondents are in fact working in the arts, with a large share currently selfemployed or working freelance. Common reasons for not working in the arts include the non-availability of arts jobs, debt, and higher pay elsewhere (Lena et al., 2014). Further, being male, white, and having a graduate degree in the arts are all predictive of being employed in the arts, while having a double major where the other major is not an arts major is predictive of not working in the arts (Frenette \& Dowd, 2018).

While the American Community Survey (ACS) does not specifically focus on arts graduates, the large sample size and breadth of questions have allowed researchers to explore the occupations, industries, and earnings of arts graduates in the USA. In contrast to findings using the SNAAP survey, authors using the ACS have found that the majority of college graduates with majors in the arts work in a non-arts field (BFAMFAPhD, 2014; Wassall \& Alper, 2018). Paulsen et al. (2021) find that graduates of the arts play a significant role in entrepreneurship and innovation in the USA, perhaps suggesting an alternative way in which arts majors can contribute to an economy beyond artistic creation. Having a college degree in the arts is associated with higher earnings among those who work in the arts, but the earnings of arts majors are still very low relative to the earnings of college graduates more generally in the USA (Wassall \& Alper, 2018).

Researchers have also looked to assess the career outcomes of arts majors outside of the USA. Using data from the Netherlands, Rengers (2002) finds that having children decreases the likelihood of employment in the arts, while having a partner increases it. Using a panel dataset from Denmark, Bille and Jensen (2018) find that among those employed in the arts in the first period of the panel, having a college degree in the arts increases the likelihood of remaining employed in the arts in the future.

As the labor market for artists differs considerably from non-arts labor markets, it is likely that artists and arts majors will be differentially impacted as well. Graduating during the recession or recovery period could have a differential impact on arts majors with regard to employment outcomes like self-employment, unemployment, part-time work, and earnings.

\subsection{Recessions and college graduates}

Especially following the Great Recession, understanding how economic fluctuations impact college graduates is a topic that has received a good deal of attention from researchers. Scholars have looked to assess whether economic downturns impact college enrollment choices. This is an interesting question as there are two potential conflicting forces. A weak labor market would encourage college attendance due to a decreased opportunity cost, but financial hardship may make it more difficult for families to send their children to college. Kisswani (2008) looked to assess the impact of the Great Depression on educational attainment. He finds some evidence that that educational attainment of white Americans was negatively affected, but no evidence 
of effects for other groups. Barr and Turner (2015) explore a similar question looking at the Great Recession and college enrollment in the USA, but with special attention paid to the impact of expanded unemployment insurance (UI) benefits. While the Great Recession had an overall positive impact on college enrollment, they find that increased availability of UI benefits increases this impact further. Hampf et al. (2020) look to assess the impact of graduating high school during a recession on college enrollment using data from 28 developed countries. They find positive impacts on college enrollment and graduation. While the overall impact of the Great Recession on enrollment has been found to be positive, this impact was heterogenous, with a larger impact for those from advantaged economic backgrounds in both the USA (Cozzolino et al., 2018) and Europe (Ayllon \&Nollenberger, 2020).

Beyond looking at the impact of graduating high school during a recession on college enrollment, attention has been paid to understanding how graduating college during a recession impacts labor market outcomes. Graduating during a recession leads to lower wages and employment for recent college graduates (Kondo, 2015; Oreopoulos et al., 2012; Rothstein, 2020). Kondo (2015) finds that this effect on wages is weaker for women than men. This negative impact on wages persists over the long-term, though more advantaged graduates are able to see their wages recover through switching to better firms over time, while less advantaged graduates, those students majoring in lower earning fields, can be permanently affected (Oreopoulos et al., 2012). While the labor market overall saw recovery from the Great Recession, new college graduate entrants appear to have suffered from a permanent structural break in employment rates (Rothstein, 2020). Interestingly, enrolling in college at a time of economic downturn has a positive impact on subsequent earnings, possibly due to these students exerting greater effort during college (Bicakova et al., 2020).

Collectively, the literature on the impacts of recessions on college graduates suggests that recessions lead to increased college enrollment, enrolling during a recession leads to greater effort exerted during college, and graduating during a recession has negative but heterogeneous effects on employment. These findings would suggest potential implications for arts majors. First, as arts majors have lower earnings than the average college graduate, negative impacts on employment and earnings for arts majors may be strong and persist longer relative to college graduates of higher earning fields. Second, arts majors enrolling in college during the recession may exert additional effort during college to offset these potential future employment affects, which could be observed through actions like pursuing a double major.

\subsection{Recessions and the arts}

When unemployment rises and incomes fall during periods of economic downturn, consumer expenditure on normal goods, and especially on luxury goods, should fall. As arts and entertainment are typically viewed by many consumers as luxury goods, the arts workforce is likely to be especially negatively affected by recessions relative to industries producing necessities. Empirical evidence suggests that spending on luxury goods was negatively impacted by the Great Recession. Consumer spending decreased on entertainment (Gao \& Kim, 2018), tourism (Alegre et al., 2013; 
Ritchie et al., 2010), and gambling (Eadington, 2011). The Great Recession had a negative impact on attendance at movies and live performances. Art organizations saw budget cuts, endowment losses, and in some cases had to close (Miringoff \& Opdycke, 2010).

Not surprisingly, artists were particularly negatively affected by the Great Recession. The unemployment rate for artists during 2008 was at a similar level to that of the overall workforce (Nichols, 2009), while in 2009 it was higher than that of the overall workforce (Nichols, 2010). This is especially notable as the unemployment rate for other "professional" workers remained significantly below that of the overall workforce during this time (Nicholas, 2010). Even in the period just after the end of the Great Recession, college graduates with majors in the arts had among the highest rates of unemployment among all majors (Carnevale et al., 2012).

Using Current Population Survey (CPS) data, Woronkowicz (2015) explored the labor market experiences of artists during the Great Recession. Artists fell as a share of the creative workforce during and after the recession and increased as a share of workers in education. Relative to other creative occupational groups, artists disproportionately shifted into self-employment or became unemployed or underemployed during and after the recession. Higher educational attainment, being male, and being married were all found to be significant predictors of maintaining quality employment as an artist following the Great Recession. While Woronkowicz (2015) focuses on the employment outcomes of artists following the Great Recession, this paper seeks to focus on both educational and employment outcomes, for arts majors rather than artists, two important gaps in the literature that this work seeks to fill.

\section{Data}

To understand how the Great Recession impacted art majors, I use individual-level data from the 2014-2018 (5-year sample) American Community Survey (ACS), accessed through the Integrated Public Use Microdata Series (IPUMS) (Ruggles et al. 2020). The ACS is run through the US census and surveys a $1 \%$ sample each year. Each yearly cross-sectional sample consists of approximately three million individuals.

In looking to identify the impact of the Great Recession on art majors, the sample is restricted to college graduates estimated to have graduated ${ }^{2}$ between 2004 and 2015. Because there is no accepted set of undergraduate college majors defined as art majors, two definitions are utilized, consistent with Paulsen et al. (2021). Core art majors include fine arts, drama and theater, music, visual and performing arts,

\footnotetext{
2 The ACS does not give year of college graduation for respondents. For the purpose of this analysis, individuals are assumed to have graduated at age 22, so graduation year is estimated as sample year minus age plus 22. Because some non-traditional graduates will have graduated at an age greater than 22 , it is possible that there is some cross-contamination among the pre, during, and post-recession periods used in this analysis. As it is more likely that graduates estimated to have graduated before the recession actually graduation during the recession than the alternative, this is likely to bias any later findings toward zero.
} 
Table 1 Descriptive statistics

\begin{tabular}{|c|c|c|c|c|c|}
\hline Variable & Full sample & Core art majors & $\begin{array}{l}\text { Extended art } \\
\text { majors }\end{array}$ & $\begin{array}{l}\text { Architecture } \\
\text { majors }\end{array}$ & Non-art majors \\
\hline Core art majors & $5.8 \%$ & & & & \\
\hline $\begin{array}{l}\text { Extended art } \\
\text { majors }\end{array}$ & $4.0 \%$ & & & & \\
\hline $\begin{array}{l}\text { Architecture } \\
\text { major }\end{array}$ & $0.7 \%$ & & & & \\
\hline Double major & $11.4 \%$ & $19.5 \%$ & $22.1 \%$ & $8.7 \%$ & $10.6 \%$ \\
\hline $\begin{array}{l}\text { Master's degree } \\
\text { or higher }\end{array}$ & $28.1 \%$ & $17.2 \%$ & $32.1 \%$ & $33.8 \%$ & $28.6 \%$ \\
\hline Employed & $86.5 \%$ & $86.3 \%$ & $85.6 \%$ & $87.1 \%$ & $86.6 \%$ \\
\hline Unemployed & $2.9 \%$ & $3.9 \%$ & $3.4 \%$ & $3.0 \%$ & $2.8 \%$ \\
\hline Earned income & $\$ 56,239$ & $\$ 43,550$ & $\$ 45,439$ & $\$ 53,699$ & $\$ 57,533$ \\
\hline $\begin{array}{l}\text { Usual hours } \\
\text { worked }\end{array}$ & 41.1 & 39.0 & 39.8 & 41.5 & 41.3 \\
\hline Self-employed & $4.3 \%$ & $10.3 \%$ & $4.6 \%$ & $6.0 \%$ & $3.9 \%$ \\
\hline Male & $44.6 \%$ & $38.2 \%$ & $29.9 \%$ & $54.8 \%$ & $45.6 \%$ \\
\hline White & $75.4 \%$ & $81.1 \%$ & $84.0 \%$ & $77.0 \%$ & $74.7 \%$ \\
\hline Black & $9.5 \%$ & $7.9 \%$ & $7.3 \%$ & $6.2 \%$ & $9.8 \%$ \\
\hline Asian & $14.2 \%$ & $10.6 \%$ & $8.9 \%$ & $15.7 \%$ & $14.6 \%$ \\
\hline Married & $42.8 \%$ & $33.9 \%$ & $41.4 \%$ & $39.1 \%$ & $43.5 \%$ \\
\hline $\begin{array}{c}\text { Number of } \\
\text { children }\end{array}$ & 0.47 & 0.30 & 0.41 & 0.31 & 0.49 \\
\hline Age & 29.0 & 28.8 & 29.0 & 29.0 & 29.0 \\
\hline Observations & 797,043 & 46,699 & 33,868 & 6,065 & 711,748 \\
\hline Weight total & $17.6 \mathrm{M}$ & $1.0 \mathrm{M}$ & $0.7 \mathrm{M}$ & $0.1 \mathrm{M}$ & $15.8 \mathrm{M}$ \\
\hline
\end{tabular}

The sample is restricted to those who have graduated with at least a Bachelors' Degree with estimated graduation years between 2004 and 2015. Sampling weights are used in calculations

commercial art and graphic design, film, video and photographic arts, art history and criticism, studio arts, and miscellaneous fine arts. ${ }^{3}$ Paulsen et al. (2021) also include the architecture major, as architects are one of the National Endowment for the Art's (NEA) arts occupations. In this analysis, architecture majors will be considered separately, consistent with Woronkowicz (2015), as the crash of the housing market during the Great Recession likely had an outsized effect on architects. Extended art majors include language and drama education, art and music education, English language and literature, and composition and speech. While these majors are less directly related to practicing as an artist, they likely provide similar skills that could allow graduates to enter into artistic fields.

Descriptive statistics are presented in Table $1 .^{4}$ The first column includes the full sample of college graduates. Columns two, three, four, and five present descriptive

\footnotetext{
3 Within the ACS fod1p and fod2p variables, there majors comprise codes 6000 to 6099 .

4 Appendix Table 7 gives a breakdown of graduates by major and year, while Appendix Table 8 gives values for the dependent variables by estimated graduation year.
} 
statistics for core art majors, extended art majors, architecture majors, and non-art majors, respectively. Given the large sample size, all pair-wise means between columns are statistically different at the $1 \%$ level. Core art majors differ from the non-art majors in educational, employment, and demographic characteristics. Educationally, core art majors are more likely to have completed a double major and less likely to have pursued an advanced degree beyond a bachelor's degree. Core art majors are more likely to be unemployed, more likely to be self-employed, work fewer hours per week, and have lower average incomes. Demographically, core art majors are less likely to be male, more likely to be white, less likely to be married, and have fewer children. Extended art majors in many, but not all, ways look more like core art majors than non-art majors. Alternatively, architecture majors in many ways look more like non-art majors.

\section{Empirical methodology}

To empirically test for the impact of graduating during the recession on a variety of outcomes, logistic and ordinary least squares (OLS) regressions will be run, using a difference-in-differences identification strategy where it is possible to compare art majors to non-art majors. Such a strategy will allow for the testing of a differential impact of having graduated during or after the Great Recession on educational decisions and employment outcomes for graduates of art fields. The time periods considered in this analysis are having graduated before the Great Recession, defined as the period 2004 to 2007, during the Great Recession, defined as the period 2008 to 2011, or after the Great Recession, defined as the period 2012 to 2015. Officially, the Great Recession lasted from December 2007 to June 2009 in the USA. Defining the graduated during the recession period to include 2008 to 2011 allows the sample to include individuals who were enrolled in college during this time. Extending this period to 2011 also allows for the inclusion of the early years of the economic recovery when unemployment rates remained far above pre-recession levels.

Where it is not possible to directly compare art majors to non-art majors, the regression specifications considered are either linear regressions for continuous outcome variables or logistic regressions for binary outcome variables of the form:

$$
\text { Outcome }_{i}=\beta_{0}+\beta_{1} \text { During }_{i}+\beta_{2} \text { After }_{i}+\beta_{X} X_{i}+\varepsilon_{i}
$$

where the sample is restricted to graduates of the art major grouping during the 2004 to 2015 period. During is a binary variable indicating having graduated during the recession period. After is a binary variable indicating having graduated after the recession period. The vector of control variables, $\boldsymbol{X}$, includes age, age squared, number of children, and binary variables indicating being married, white, Black, Asian, Hispanic, male, the ACS sample year, and state of residence. 
Where it is possible to directly compare art majors to non-art majors, the difference-in-differences regression specifications considered are either linear regressions for continuous outcome variables or logistic regressions for binary outcome variables of the form:

$$
\text { Outcome }_{i}=\gamma_{0}+\gamma_{1} \text { During }_{i}+\gamma_{2} \operatorname{Arts}_{i}+\gamma_{3} \text { During }_{i} * \operatorname{Arts}_{i}+\gamma_{X} \boldsymbol{X}_{i}+\gamma_{\boldsymbol{I}} \boldsymbol{X}_{i} * \operatorname{Arts}_{i}+\eta_{i}
$$

or

$$
\text { Outcome }_{i}=\delta_{0}+\delta_{1} \text { After }_{i}+\delta_{2} \operatorname{Arts}_{i}+\delta_{3} \text { After }_{\mathrm{i}} * \operatorname{Arts}_{i}+\delta_{\boldsymbol{X}} \boldsymbol{X}_{i}+\delta_{\boldsymbol{I}} \boldsymbol{X}_{i} * \operatorname{Arts}_{i}+\rho_{i}
$$

where the sample is restricted to graduates of the art major grouping and non-art majors during the pre-recession period and either the during or after recession period. To allow for the possibility of a differential impact of demographic characteristics on art majors relative to non-art majors, as would be consistent with the differential labor market experiences of artists documented in the literature, the vector of demographic characteristics is interacted with the art major variable. The coefficient of interest here is the coefficient on the interaction of the period considered and the arts major variable. For logit regressions, marginal effects estimated at means are reported rather than logit coefficients.

Dependent variables analyzed include factors related to educational decisions and employment-related outcomes. As recent work by Modestino et al. (2020) finds that employers increased their skill requirements on job postings during the Great Recession, it is possible that students made educational choices to reflect this increase in skill requirements. As such, dependent variables related to educational decisions include binary variables indicating graduating with a major in the arts, graduating with a double major, and pursuing a higher degree beyond a bachelor's degree. Like Woronkowicz (2015), I also consider employment-related outcomes. Among employment-related outcomes, I look to understand how graduating during the recession impacts employment status, hours and earnings, and type of employment, outcomes commonly considered in the literature. Dependent variables related to employment outcomes include earned income, weekly hours worked, and binary variables indicating being employed, being unemployed, being self-employed, and working in an occupation related to the major degree field.

\section{Results}

\subsection{Education-related outcomes}

To assess the impact of the Great Recession on art majors, the first set of outcomes considered are education-related outcomes. Table 2 presents regression results looking to understand the impact of graduating during and after the recession on majoring in the arts. Three regressions were run, with dependent variables indicating having majored in a core art major, an extended art major, or an architecture major. ${ }^{5}$ Having

\footnotetext{
5 Appendix Tables 9 and 10 break the core art major variable down further into the individual core art majors.
} 
Table 2 Logit regression: dependent variable is binary for whether or not a graduate of major group

\begin{tabular}{llll}
\hline Graduation period & $\begin{array}{l}\text { Core art majors } \\
(1)\end{array}$ & $\begin{array}{l}\text { Extended art majors } \\
(2)\end{array}$ & $\begin{array}{l}\text { Architecture majors } \\
(3)\end{array}$ \\
\hline Graduated during recession & $-0.002^{* * *}$ & $0.002^{* * *}$ & $0.001^{* * *}$ \\
& $(0.000)$ & $(0.000)$ & $(0.000)$ \\
Graduated after recession & $-0.003^{* * *}$ & $0.001^{*}$ & $0.002^{* * *}$ \\
& $(0.000)$ & $(0.000)$ & $(0.000)$ \\
Mean & $5.8 \%$ & $4.0 \%$ & $0.7 \%$ \\
Observations & 797,043 & 797,043 & 797,043 \\
Pseudo- $R$-squared & 0.024 & 0.022 & 0.015 \\
\hline
\end{tabular}

Demographic controls include age and age squared, number of children, and binary variables indicating being married, white, Black, Asian, Hispanic, male, and sample year. Additionally, a male*married interaction is included. Demographic controls are also interacted with the arts major grouping. State fixed effects are also included. The omitted graduation period is the before recession period, so coefficients reported are relative to having graduated during the recession. Coefficient estimates reported are marginal effects estimated at means. Standard errors are in parenthesis. Sampling weights are used in calculations

$* * * p<0.01 ; * * p<0.05 ;$ and $* p<0.1$

graduated during or after the Great Recession decreased the likelihood that a graduate graduated with a major in a core art field by 0.2 and $0.3 \%$ points, respectively. As about $5.8 \%$ of graduates during the sample period graduated with a major in a core art field, those changes represent falls of 3.4 and 5.2\%. While students were less likely to major in a core art field, graduating during or after the Great Recession led to an increase in the likelihood of majoring in an extended art field or architecture. Though the data cannot tell us why graduates selected the fields they selected, the findings of Zafar (2012) would suggest that the desire for parental approval may play a role. A student's parents may have felt worried about their child's future job security given the economic conditions, and art or music education may have felt like a safer choice than fine art or music performance given the potential to work in the arts or education, which would lead to a negative impact on majoring in the core art fields and a positive impact on majoring in the extended art fields. The positive coefficients in the architecture regression are surprising, though if parental influence played a role, it is possible that confidence in the recovery of the housing sector may have exceeded confidence in the recovery of the arts and entertainment industry.

Table 3 presents results looking to understand how graduating during or after the recession impacted whether graduates pursued an advanced degree or completed a double major. Specifications (1)-(6) present difference-in-differences results looking at the impact of graduating during or after the Great Recession on arts majors' pursuit of advanced degrees. Among non-art college graduates, having graduated during or after the Great Recession had a positive and significant impact on the likelihood of 
Table 3 Logit regression: education dependent variables

\begin{tabular}{|c|c|c|c|}
\hline Variables & Core art majors & Extended art majors & Architecture majors \\
\hline Dependent variable_-advanced degree & (1) & (2) & (3) \\
\hline Graduated during recession & $\begin{array}{l}0.002 * * * \\
(0.001)\end{array}$ & $\begin{array}{l}0.003 * * * \\
(0.001)\end{array}$ & $\begin{array}{l}0.002 * * * \\
(0.001)\end{array}$ \\
\hline During*major interaction & $\begin{array}{l}0.003 \\
(0.002)\end{array}$ & $\begin{array}{l}-0.019 * * * \\
(0.002)\end{array}$ & $\begin{array}{l}0.044 * * * \\
(0.005)\end{array}$ \\
\hline Major mean pre-recession & $23.5 \%$ & $44.2 \%$ & $39.2 \%$ \\
\hline Observations & 543,893 & 535,532 & 515,992 \\
\hline Pseudo- $R$-squared & $\begin{array}{l}0.034 \\
(4)\end{array}$ & $\begin{array}{l}0.031 \\
(5)\end{array}$ & $\begin{array}{l}0.031 \\
(6)\end{array}$ \\
\hline Graduated after recession & $\begin{array}{l}0.045^{* * * *} \\
(0.001)\end{array}$ & $\begin{array}{l}0.047 * * * \\
(0.001)\end{array}$ & $\begin{array}{l}0.045 * * * \\
(0.001)\end{array}$ \\
\hline After*major interaction & $\begin{array}{l}-0.026 * * * \\
(0.003)\end{array}$ & $\begin{array}{l}-0.017 * * * \\
(0.003)\end{array}$ & $\begin{array}{l}0.089 * * * \\
(0.009)\end{array}$ \\
\hline Observations & 491,429 & 483,309 & 465,996 \\
\hline Pseudo- $R$-squared & 0.082 & 0.081 & 0.079 \\
\hline Dependent variable_-double major & (7) & $(8)$ & $(9)$ \\
\hline Graduated during recession & $\begin{array}{l}-0.002 * * * \\
(0.000)\end{array}$ & $\begin{array}{l}-0.001 * * * \\
(0.000)\end{array}$ & $\begin{array}{l}-0.002 * * * \\
(0.000)\end{array}$ \\
\hline During*major interaction & $\begin{array}{l}0.003 * * * \\
(0.001)\end{array}$ & $\begin{array}{l}0.008 * * * \\
(0.001)\end{array}$ & $\begin{array}{l}-0.011 * * * \\
(0.003)\end{array}$ \\
\hline Major mean pre-recession & $18.9 \%$ & $21.7 \%$ & $8.4 \%$ \\
\hline Observations & 543,893 & 535,532 & 515,992 \\
\hline Pseudo- $R$-squared & $\begin{array}{l}0.012 \\
(10)\end{array}$ & $\begin{array}{l}0.013 \\
(11)\end{array}$ & $\begin{array}{l}0.009 \\
(12)\end{array}$ \\
\hline Graduated after recession & $\begin{array}{l}-0.007 * * * \\
(0.001)\end{array}$ & $\begin{array}{l}-0.005 * * * \\
(0.001)\end{array}$ & $\begin{array}{l}-0.005^{* * * *} \\
(0.001)\end{array}$ \\
\hline After*major interaction & $\begin{array}{l}0.006 * * * \\
(0.002)\end{array}$ & $\begin{array}{l}0.004 * * \\
(0.002)\end{array}$ & $\begin{array}{l}-0.023 * * * \\
(0.005)\end{array}$ \\
\hline Observations & 491,429 & 483,309 & 465,996 \\
\hline Pseudo- $R$-squared & 0.012 & 0.012 & 0.009 \\
\hline
\end{tabular}

Demographic controls include age and age squared, number of children, and binary variables indicating being married, white, Black, Asian, Hispanic, male, and sample year. Additionally, a male*married interaction is included. Demographic controls are also interacted with the arts major grouping. State fixed effects are also included. Coefficient estimates reported are marginal effects estimated at means. Standard errors are in parenthesis. Sampling weights are used in calculations

$* * * p<0.01 ; * * p<0.05 ;$ and $* p<0.1$

pursuing an advanced degree. For graduates with majors in the arts, core arts majors were significantly less likely to pursue an advanced degree if having graduated after the recession and extended arts majors were significantly less likely to pursue an advanced degree if graduating either during or after the recession, while architecture majors were significantly more likely to pursue an advanced degree having graduated during either the during or after period. A different story is observed when looking at the impact on double majors in specifications (7)-(12). Among non-art graduates, 
having graduated during or after the Great Recession had a negative and significant impact on the likelihood of double majoring. For graduates with majors in the arts, core and extended arts majors were significantly more likely to complete a double major if graduating either during or after the recession, while architecture majors were significantly less likely to complete a double major having graduated during either the during or after period.

While both completing a double major and pursuing an advanced degree are forms of acquiring additional human capital, the costs and consequences of these two actions differ considerably. In the US educational system, students typically need around 120 credits to complete a 4-year degree. These credits often come from completing a general education core, completing the requirements for a major field of study, and completing additional credits (often in the form of minor fields of study or a second major) to achieve 120 total. For many students, it is possible to complete a second major within the 4-year degree, so while this may be seen as additional human capital to an employer, there may not be a direct financial cost, the only cost being additional effort exerted in completing the requirements for the second major. Completing an advanced degree, most commonly a degree at the master's level, typically requires an additional 1 to 2 years of coursework beyond the 4-year degree and also requires a financial cost. It is not surprising then that core and extended arts majors would be more likely to pursue a double major, which gives additional human capital without financial cost, rather than an advanced degree, in an attempt to improve credentials when entering a weaker labor market. For architecture majors, a master's degree, which delays entry into the labor force, may have been seen as the preferred option given the especially compromised state of their labor market.

\subsection{Employment-related outcomes}

Beyond the educational outcomes considered, I look to understand the impact of the Great Recession on a number of employment-related outcomes for art majors. Table 4 presents difference-in-differences logit regression results where the dependent variables are binary variables indicating being employed, being unemployed, and being self-employed. For specifications (1)-(6), the dependent variable is a binary variable which takes on a one if the individual is employed. Among all graduates, having graduated during the Great Recession had a small, negative impact on the likelihood of being employed. While graduating during the Great Recession did not have a differential impact the likelihood of being employed for core arts majors, both extended arts and architecture majors were significantly more likely to be employed if having graduated during the recession. While this runs contrary to expectation, it is possible that the additional human capital acquired, through increased double majoring for extended arts majors and through pursuing advanced degrees for architecture majors, could be driving this positive impact. With the exception of the interaction of architecture and graduating after, all coefficients in the graduating after regressions indicate a positive impact on the likelihood of being employed. While those graduating before the recession may have encountered unemployment during the recession period, and that negative impact may have persisted, those graduating after the 
Table 4 Logit regression: employment dependent variables

\begin{tabular}{|c|c|c|c|}
\hline Variables & Core art majors & Extended art majors & Architecture majors \\
\hline Dependent variable_employed & (1) & (2) & (3) \\
\hline Graduated during recession & $\begin{array}{l}-0.001^{* * *} \\
(0.000)\end{array}$ & $\begin{array}{l}-0.001^{* * *} * \\
(0.000)\end{array}$ & $\begin{array}{l}-0.001^{* * * *} \\
(0.000)\end{array}$ \\
\hline During*major interaction & $\begin{array}{l}0.001 \\
(0.001)\end{array}$ & $\begin{array}{l}0.005^{* * *} \\
(0.001)\end{array}$ & $\begin{array}{l}0.012 * * * \\
(0.002)\end{array}$ \\
\hline Major mean pre-recession & $87.1 \%$ & $86.2 \%$ & $89.9 \%$ \\
\hline Observations & 475,881 & 467,443 & 450,766 \\
\hline Pseudo- $R$-squared & $\begin{array}{l}0.109 \\
(4)\end{array}$ & $\begin{array}{l}0.111 \\
(5)\end{array}$ & $\begin{array}{l}0.110 \\
(6)\end{array}$ \\
\hline Graduated after recession & $\begin{array}{l}0.022 * * * \\
(0.001)\end{array}$ & $\begin{array}{l}0.022 * * * \\
(0.001)\end{array}$ & $\begin{array}{l}0.022 * * * \\
(0.001)\end{array}$ \\
\hline After*major interaction & $\begin{array}{l}0.005^{* * * *} \\
(0.002)\end{array}$ & $\begin{array}{l}0.023^{* * *} * \\
(0.002)\end{array}$ & $\begin{array}{l}-0.038 * * * \\
(0.007)\end{array}$ \\
\hline Observations & 405,794 & 397,806 & 383,635 \\
\hline Pseudo- $R$-squared & 0.097 & 0.098 & 0.097 \\
\hline Dependent variable—unemployed & (7) & (8) & (9) \\
\hline Graduated during recession & $\begin{array}{l}0.001 * * * \\
(0.000)\end{array}$ & $\begin{array}{l}0.001^{* * *} \\
(0.000)\end{array}$ & $\begin{array}{l}0.001 \text { *** } \\
(0.000)\end{array}$ \\
\hline During*major interaction & $\begin{array}{l}0.002 * * * \\
(0.000)\end{array}$ & $\begin{array}{l}-0.003 * * * \\
(0.001)\end{array}$ & $\begin{array}{l}-0.014 * * * \\
(0.001)\end{array}$ \\
\hline Major mean pre-recession & $3.0 \%$ & $2.5 \%$ & $2.7 \%$ \\
\hline Observations & 475,881 & 467,443 & 450,766 \\
\hline Pseudo- $R$-squared & $\begin{array}{l}0.027 \\
(10)\end{array}$ & $\begin{array}{l}0.028 \\
(11)\end{array}$ & $\begin{array}{l}0.027 \\
(12)\end{array}$ \\
\hline Graduated after recession & $\begin{array}{l}-0.008 * * * \\
(0.000)\end{array}$ & $\begin{array}{l}-0.008 * * * \\
(0.000)\end{array}$ & $\begin{array}{l}-0.008 * * * \\
(0.000)\end{array}$ \\
\hline After*major interaction & $\begin{array}{l}0.000 \\
(0.001)\end{array}$ & $\begin{array}{l}0.002 \\
(0.001)\end{array}$ & $\begin{array}{l}0.008^{* * *} * \\
(0.003)\end{array}$ \\
\hline Observations & 405,794 & 397,806 & 383,635 \\
\hline Pseudo- $R$-squared & 0.039 & 0.040 & 0.039 \\
\hline Dependent variable—self-employed & (13) & (14) & $(15)$ \\
\hline Graduated during recession & $\begin{array}{l}-0.002 * * * \\
(0.000)\end{array}$ & $\begin{array}{l}-0.002 * * * \\
(0.000)\end{array}$ & $\begin{array}{l}-0.002^{* * * *} \\
(0.000)\end{array}$ \\
\hline During*major interaction & $\begin{array}{l}0.002 * * * \\
(0.001)\end{array}$ & $\begin{array}{l}0.012 * * * \\
(0.001)\end{array}$ & $\begin{array}{l}-0.011 * * * \\
(0.001)\end{array}$ \\
\hline Major mean pre-recession & $13.2 \%$ & $6.4 \%$ & $9.0 \%$ \\
\hline Observations & 425,211 & 417,602 & 403,262 \\
\hline Pseudo- $R$-squared & $\begin{array}{l}0.032 \\
(16)\end{array}$ & $\begin{array}{l}0.022 \\
(17)\end{array}$ & $\begin{array}{l}0.022 \\
(18)\end{array}$ \\
\hline Graduated after recession & $\begin{array}{l}-0.002^{* * *} \\
(0.001)\end{array}$ & $\begin{array}{l}-0.003^{* * * *} \\
(0.001)\end{array}$ & $\begin{array}{l}-0.003^{* * * *} \\
(0.001)\end{array}$ \\
\hline After*major interaction & $\begin{array}{l}0.012 * * * \\
(0.001)\end{array}$ & $\begin{array}{l}0.013 * * * \\
(0.002)\end{array}$ & $\begin{array}{l}0.020 * * * \\
(0.005)\end{array}$ \\
\hline Observations & 362,506 & 355,406 & 343,136 \\
\hline Pseudo- $R$-squared & 0.043 & 0.033 & 0.034 \\
\hline
\end{tabular}


Table 4 (continued)

Demographic controls include age and age squared, number of children, and binary variables indicating being married, white, Black, Asian, Hispanic, male, and sample year. Additionally, a male*married interaction is included. Demographic controls are also interacted with the arts major grouping. State fixed effects are also included. Coefficient estimates reported are marginal effects estimated at means. Standard errors are in parenthesis. Sampling weights are used in calculations

$* * * p<0.01 ; * * p<0.05$, and $* p<0.1$

recession would not have experienced such an impact. Expansions of unemployment insurance in the USA may have increased the duration of unemployment for job losers during the recession, and evidence suggests that the long-term unemployed faced significant negative effects from unemployment during this period (Ghayad, 2013).

The impact of graduating during or after the Great Recession on unemployment is explored in specifications (7)-(12). In these specifications, the dependent variable is a binary variable indicating being unemployed. Similar to the employment regressions, for all college graduates graduating during the recession had a positive and significant impact on the likelihood of being unemployed and graduating after the recession has a negative and significant impact on the likelihood of being unemployed. Graduating during the Great Recession had a positive and significant impact on the likelihood of unemployment for core arts majors, but a negative impact for extended arts majors and architecture majors. Graduating after the recession did not have a significant differential impact on the likelihood of unemployment for core and extended arts majors but did have a positive impact on the likelihood of unemployment for architecture majors.

Last, the impact of graduating during or after the Great Recession on the likelihood of being self-employed is considered in specifications (13)-(18). For all graduates, graduating during or after the Great Recession had a negative and significant impact on the likelihood of being self-employed. Interestingly, for core and extended arts majors having graduated during or after the recession had a positive impact on the likelihood of being self-employed. As gaining traditional employment in an artsrelated occupation may have been difficult during this time, self-employment may have served as a viable alternative to pursue artistic creation.

The findings on unemployment and self-employment are in line with the findings of Woronkowicz (2015). Woronkowicz (2015) finds that the Great Recession increased unemployment and self-employment for artists, which aligns with findings of a positive impact on unemployment and self-employment of core art majors in this study.

Among those who are employed, Table 5 looks to assess the impact of graduating during or after the Great Recession on earnings and hours worked. Specifications (1)-(6) look at the impact of graduating during or after the recession on earnings. For all college graduates, the impact on graduating during the recession on earnings is insignificant, while the impact of graduating after is positive and significant. The impact on arts major is starkly different. Graduating during the recession has negative and significant impacts on earnings for core and extended arts majors of about $\$ 1000$ and $\$ 2000$, respectively. Graduating after the recession 
Table 5 Linear regression: earnings and hours worked dependent variables

\begin{tabular}{|c|c|c|c|}
\hline Variables & Core art majors & Extended art majors & Architecture majors \\
\hline Dependent variable-earned income & (1) & (2) & (3) \\
\hline Graduated during recession & $\begin{array}{l}-15.6 \\
(71.1)\end{array}$ & $\begin{array}{l}23.9 \\
(71.5)\end{array}$ & $\begin{array}{l}8.8 \\
(72.3)\end{array}$ \\
\hline During*major interaction & $\begin{array}{l}-1020.9^{* * *} \\
(167.3)\end{array}$ & $\begin{array}{l}-1994.3^{* * *} \\
(206.4)\end{array}$ & $\begin{array}{l}3462.9 * * * \\
(400.6)\end{array}$ \\
\hline Major mean pre-recession & $\$ 54,709$ & $\$ 58,191$ & $\$ 65,844$ \\
\hline Observations & 425,211 & 417,602 & 403,262 \\
\hline$R$-squared & $\begin{array}{l}0.104 \\
(4)\end{array}$ & $\begin{array}{l}0.103 \\
(5)\end{array}$ & $\begin{array}{l}0.101 \\
(6)\end{array}$ \\
\hline Graduated after recession & $\begin{array}{l}3202.7 * * * \\
(125.8)\end{array}$ & $\begin{array}{l}3299.2 * * * \\
(127.1)\end{array}$ & $\begin{array}{l}3230.2 * * * \\
(128.9)\end{array}$ \\
\hline After*major interaction & $\begin{array}{l}361.0 \\
(257.5)\end{array}$ & $\begin{array}{l}-3350.8 * * * \\
(325.1)\end{array}$ & $\begin{array}{l}4202.8 * * * \\
(734.1)\end{array}$ \\
\hline Observations & 362,506 & 355,406 & 343,136 \\
\hline$R$-squared & 0.147 & 0.145 & 0.144 \\
\hline Dependent variable —usual hours worked & (7) & $(8)$ & (9) \\
\hline Graduated during recession & $\begin{array}{l}0.094 * * * \\
(0.013)\end{array}$ & $\begin{array}{l}0.111 * * * \\
(0.013)\end{array}$ & $\begin{array}{l}0.114 * * * \\
(0.014)\end{array}$ \\
\hline During*major interaction & $\begin{array}{l}0.200 * * * \\
(0.044)\end{array}$ & $\begin{array}{l}0.125 * * \\
(0.051)\end{array}$ & $\begin{array}{l}0.180^{*} \\
(0.098)\end{array}$ \\
\hline Major mean pre-recession & 40.3 & 41.3 & 43.2 \\
\hline Observations & 425,211 & 417,602 & 403,262 \\
\hline$R$-squared & $\begin{array}{l}0.057 \\
(10)\end{array}$ & $\begin{array}{l}0.056 \\
(11)\end{array}$ & $\begin{array}{l}0.056 \\
(12)\end{array}$ \\
\hline Graduated after recession & $\begin{array}{l}0.695 * * * \\
(0.026)\end{array}$ & $\begin{array}{l}0.708 * * * \\
(0.026)\end{array}$ & $\begin{array}{l}0.696 * * * \\
(0.026)\end{array}$ \\
\hline After*major interaction & $\begin{array}{l}1.008^{* * * *} \\
(0.076)\end{array}$ & $\begin{array}{l}0.599 * * * \\
(0.093)\end{array}$ & $\begin{array}{l}-0.723 * * * \\
(0.172)\end{array}$ \\
\hline Observations & 362,506 & 355,406 & 343,136 \\
\hline$R$-squared & 0.062 & 0.061 & 0.060 \\
\hline
\end{tabular}

Demographic controls include age and age squared, number of children, and binary variables indicating being married, white, Black, Asian, Hispanic, male, and sample year. Additionally, a male*married interaction is included. Demographic controls are also interacted with the arts major grouping. State fixed effects are also included. Standard errors are in parenthesis. Sampling weights are used in calculations

$* * * p<0.01 ; * * p<0.05$, and $* p<0.1$

has an insignificant differential impact on earnings for core arts majors, while the negative and significant differential impact for extended arts majors more than cancels out the positive coefficient on the graduated after term. For architecture majors, impacts of graduating during and after the recession on earnings are large and positive. This is likely attributable though to their increased likelihood of pursuing an advanced degree, which leads to higher earnings. 
The impact of graduating during or after the Great Recession on usual hours worked is assessed in specifications (7)-(12). The impact of graduating during or after the recession is positive and significant for all graduates. The differential impact on hours worked of graduating during or after the recession for core and extended arts majors is large, positive, and significant. For architecture majors, graduating during the recession had a positive, marginally significant differential impact on hours worked but graduating after had a negative and significant impact.

Table 6 looks at the impact of graduating during or after the recession on getting a job in one's major field of study. As not all college majors lead to an easily defined post-graduation job, here the impact is looked at for core art majors, along with a few other major fields that have clearly defined post-graduation occupations. Graduating during and after the recession has positive impacts for core art majors on employment in the arts. This is likely attributable to the increase in self-employment seen previously. The impact of graduating during the recession on employment in one's major field is study is mixed for the other major fields considered. Engineering majors also see a positive impact on working in their major field, while nursing majors see no impact, and education and accounting majors see negative and significant impacts.

\section{Conclusions}

This paper examines the impact of the Great Recession on college graduates with majors in the arts. As economic downturns hit fields that rely on discretionary spending, like the arts, especially hard, arts majors have the potential to be particularly negatively impacted. Using American Community Survey data, this paper looks to assess the impact of graduating during or shortly after the Great Recession on educational and labor market outcomes for arts majors relative to graduating shortly prior to the recession. This study finds a sizeable negative impact of graduating during or after the Great Recession on majoring in a core art field, but a positive impact on majoring in an extended art field or architecture. Relative to non-art majors, graduating during or after the recession increased the likelihood that core and extended art majors double majored and increased the likelihood of architecture majors completing an advanced degree. Regarding unemployment, graduating during the Great Recession is found to increase the likelihood of unemployment for core art majors but decrease the likelihood for extended art and architecture majors relative to nonart majors. Graduating during the recession period increased the likelihood of selfemployment for core and extended arts majors and led to decreased earnings despite leading to increased hours worked. Overall, the Great Recession had notable impacts on both the educational choices and labor market outcomes of college graduates with majors in the arts.

These findings are important both for arts majors and the arts as well as for the economy more broadly. Directly, decreases in the share of college graduates majoring in the arts will negatively impact the pipeline of potential artists. Additionally, long-term negative impacts on employment and earnings may further 


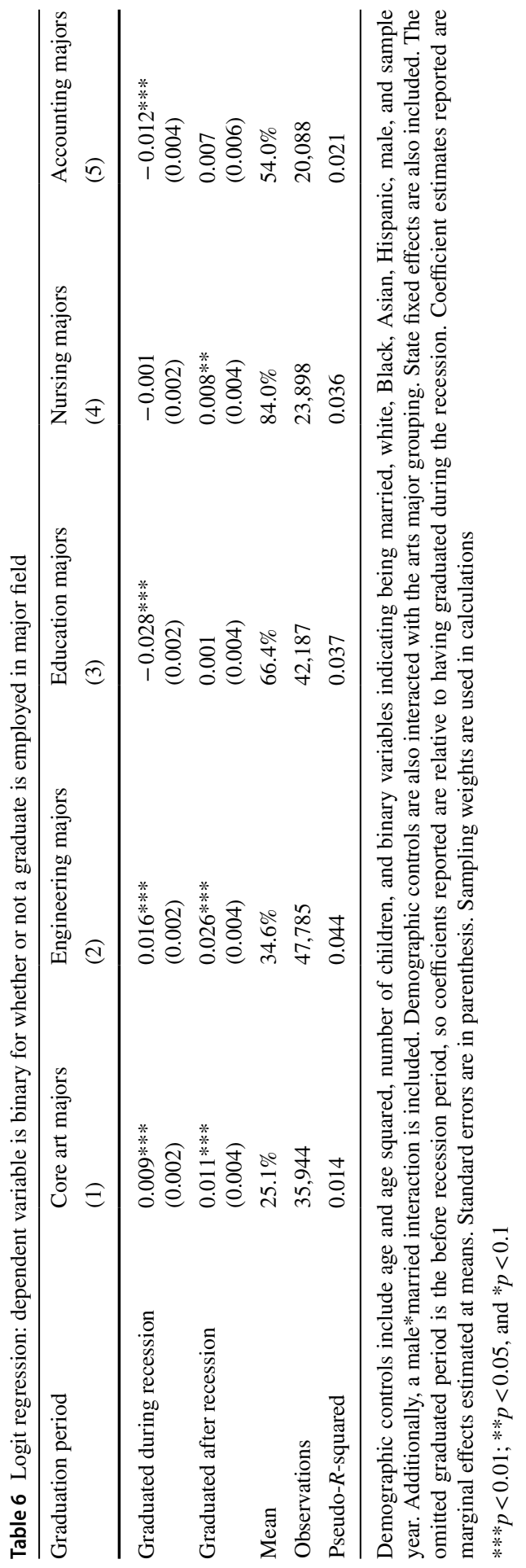


negatively impact the pipeline of potential artists, as higher pay outside of the arts is the most important factor arts majors report for choosing to work outside of the arts (Lena et al., 2014). As it relates to the broader economy, creativity is believed to be an important driver of economic growth, and recent work by Paulsen et al. (2021) finds that college graduates with majors in the arts also play an important role in entrepreneurship and innovation in the US economy. A shrinkage of the pipeline of arts majors could in turn have a negative impact not just on artistic creation but also on entrepreneurship and innovation.

There are likely many potential policy options that could alleviate the negative impact of future recessions on arts majors. Debt is one reason arts graduates commonly cite for not working in the arts (Lena et al., 2014). As such, student loan debt relief could be considered as a policy tool to alleviate the negative impacts of recessions on arts graduates. The pausing of federal student loan payments has been a policy tool used during the COVID-19 pandemic. Targeted relief, including direct loan forgiveness or targeted pauses in payments or interest accumulation geared toward lower earning college graduates, could particularly alleviate some of the challenges faced by arts graduates. The Great Recession was also a time of funding cuts for the arts (Miringoff \& Opdycke, 2010). Rather than cutting funding for the arts during times of economic downturn, increasing funding to help alleviate cuts in private consumer spending on the arts would help to lessen some of the negative impact on arts graduates.

This work is limited in a number of ways. While the ACS has the benefit of having a large enough sample size to allow for the analysis of detailed college majors, there are important educational variables not included in the survey which could've improved the findings of this work. Graduation year is not given, which may have caused cross contamination across groups, potentially biasing the coefficients of interest toward zero. Additionally, the ACS lacks information pertaining to the institution from which students graduated, which may be related to the major field of study selected. Beyond college major, other educational variables that may have been impacted, like minor fields of study and grade point average, are also not given. Improved data quality could allow for stronger causal language to be used in discussing the impact of the recession on the various outcomes considered. Without a richer set of control variables, I exercise caution in attributing causal impacts to the identified effects. Beyond data limitations, this study is also limited in that graduates are observed at a single point in time within a relatively short window following the recession.

Future working examining the impact of the Great Recession and recessions generally could improve upon this current work in multiple ways. Analysis using panel data would allow for the telling of a more complete employment story for art majors graduating during recessionary periods. While a time period relatively shortly after the recession was analyzed, looking at the impact over a longer window could be informative as data becomes available. Using a data source with more detailed education variables could also allow for a more complete analysis of the educational consequences of graduating during a recessionary period, as other factors like GPA, minor fields of study, participation in clubs, and part-time work during college may have also been affected. 


\section{Appendix}

See Tables 7, 8 9, and 10.

Table 7 Counts of graduates by arts major grouping and graduation year

\begin{tabular}{lllll}
\hline Graduation year & Full sample & Core art majors & $\begin{array}{l}\text { Extended art } \\
\text { majors }\end{array}$ & $\begin{array}{l}\text { Archi- } \\
\text { tecture } \\
\text { majors }\end{array}$ \\
\hline 2004 & 73,818 & 4046 & 3236 & 584 \\
2005 & 73,775 & 4052 & 3191 & 544 \\
2006 & 72,411 & 4129 & 3096 & 534 \\
2007 & 73,088 & 4269 & 3161 & 551 \\
2008 & 72,006 & 4164 & 3165 & 591 \\
2009 & 70,623 & 4117 & 2981 & 613 \\
2010 & 69,825 & 4289 & 3040 & 576 \\
2011 & 67,621 & 4162 & 2916 & 506 \\
2012 & 66,666 & 4107 & 2802 & 524 \\
2013 & 61,357 & 3728 & 2579 & 433 \\
2014 & 53,674 & 3205 & 2175 & 354 \\
2015 & 42,179 & 2431 & 1526 & 255 \\
\hline
\end{tabular}

Table 8 Dependent variables for full sample by graduation year

\begin{tabular}{llllllll}
\hline $\begin{array}{l}\text { Graduation } \\
\text { year }\end{array}$ & $\begin{array}{l}\text { Advanced } \\
\text { degree } \\
(\%)\end{array}$ & $\begin{array}{l}\text { Double } \\
\text { major } \\
(\%)\end{array}$ & $\begin{array}{l}\text { Employed } \\
(\%)\end{array}$ & $\begin{array}{l}\text { Unem- } \\
\text { ployed } \\
(\%)\end{array}$ & $\begin{array}{l}\text { Earned } \\
\text { income }\end{array}$ & $\begin{array}{l}\text { Usual } \\
\text { hours } \\
\text { worked }\end{array}$ & $\begin{array}{l}\text { Self- } \\
\text { employed } \\
(\%)\end{array}$ \\
\hline 2004 & 37.8 & 10.8 & 87.5 & 2.2 & $\$ 74,702$ & 42.1 & 6.5 \\
2005 & 37.0 & 10.9 & 87.6 & 2.1 & $\$ 71,950$ & 42.1 & 6.3 \\
2006 & 36.4 & 11.4 & 87.6 & 2.3 & $\$ 67,684$ & 42.1 & 5.5 \\
2007 & 35.2 & 11.6 & 88.0 & 2.4 & $\$ 64,676$ & 42.2 & 5.3 \\
2008 & 33.2 & 11.7 & 87.8 & 2.5 & $\$ 60,962$ & 42.1 & 4.6 \\
2009 & 31.2 & 11.6 & 87.7 & 2.6 & $\$ 56,992$ & 41.9 & 4.3 \\
2010 & 28.3 & 11.7 & 87.9 & 2.6 & $\$ 53,678$ & 41.6 & 3.9 \\
2011 & 24.8 & 11.4 & 86.8 & 3.0 & $\$ 49,562$ & 41.1 & 3.6 \\
2012 & 20.9 & 11.6 & 86.2 & 3.1 & $\$ 45,340$ & 40.5 & 3.1 \\
2013 & 17.3 & 11.7 & 84.7 & 3.9 & $\$ 40,952$ & 39.6 & 2.7 \\
2014 & 13.3 & 11.4 & 82.5 & 4.4 & $\$ 36,739$ & 38.6 & 2.4 \\
2015 & 10.7 & 11.2 & 80.4 & 4.9 & $\$ 33,550$ & 37.7 & 2.4 \\
\hline
\end{tabular}


Table 9 Logit regression: dependent variable is binary for whether or not a graduate of major group

\begin{tabular}{llllll}
\hline $\begin{array}{l}\text { Graduation } \\
\text { period }\end{array}$ & Fine art major & $\begin{array}{l}\text { Drama and } \\
\text { theater arts } \\
\text { major }\end{array}$ & Music major & $\begin{array}{l}\text { Visual and } \\
\text { performing arts } \\
\text { major }\end{array}$ & $\begin{array}{l}\text { Commercial art } \\
\text { and graphic design } \\
\text { major }\end{array}$ \\
\hline $\begin{array}{l}\text { Graduated during } \\
\text { recession }\end{array}$ & 0.000 & $0.000^{* * *}$ & $-0.001 * * *$ & $-0.000^{* * *}$ & $-0.001^{* * *}$ \\
Graduated after & $0.001 * * *$ & $0.001 * * *$ & $-0.001 * * *$ & $-0.000^{* * *}$ & $-0.002^{* * *}$ \\
recession & $(0.000)$ & $(0.000)$ & $(0.000)$ & $(0.000)$ & $(0.000)$ \\
Mean & $1.1 \%$ & $0.7 \%$ & $1.0 \%$ & $0.3 \%$ & $1.6 \%$ \\
Observations & 797,043 & 797,043 & 797,043 & 797,043 & 797,043 \\
Pseudo- $R-$ & 0.019 & 0.041 & 0.015 & 0.036 & 0.015 \\
squared & & & & & \\
\hline
\end{tabular}

Demographic controls include age and age squared, number of children, and binary variables indicating being married, white, Black, Asian, Hispanic, male, and sample year. Additionally, a male*married interaction is included. Demographic controls are also interacted with the arts major grouping. State fixed effects are also included. The omitted graduated period is the before recession period, so coefficients reported are relative to having graduated during the recession. Coefficient estimates reported are marginal effects estimated at means. Standard errors are in parenthesis. Sampling weights are used in calculations

$* * * p<0.01 ; * * p<0.05 ;$ and $* p<0.1$

Table 10 Logit regression: dependent variable is binary for whether or not a graduate of major group

\begin{tabular}{lllll}
\hline Graduation period & $\begin{array}{l}\text { Film, video, and pho- } \\
\text { tographic arts major }\end{array}$ & $\begin{array}{l}\text { Art history and } \\
\text { criticism major }\end{array}$ & Studio major & $\begin{array}{l}\text { Miscellaneous } \\
\text { fine arts major }\end{array}$ \\
\hline Graduated during recession & $\begin{array}{l}0.000^{* * *} \\
(0.000)\end{array}$ & $-0.000^{* * *}$ & $-0.000^{* * *}$ & $\begin{array}{l}0.000^{* * *} \\
(0.000)\end{array}$ \\
Graduated after recession & 0.000 & $(0.000)$ & $(0.000)$ & $-0.000^{* * *}$ \\
Mean & $(0.000)$ & $(0.000)$ & $(0.000)$ & $(0.000)$ \\
Observations & $0.6 \%$ & $0.3 \%$ & $0.3 \%$ & $0.1 \%$ \\
Pseudo- $R$-squared & 797,043 & 797,043 & 797,043 & 797,043 \\
& 0.045 & 0.067 & 0.029 & 0.030
\end{tabular}

Demographic controls include age and age squared, number of children, and binary variables indicating being married, white, Black, Asian, Hispanic, male, and sample year. Additionally, a male*married interaction is included. Demographic controls are also interacted with the arts major grouping. State fixed effects are also included. The omitted graduated period is the before recession period, so coefficients reported are relative to having graduated during the recession. Coefficient estimates reported are marginal effects estimated at means. Standard errors are in parenthesis. Sampling weights are used in calculations

$* * * p<0.01 ; * * p<0.05$, and $* p<0.1$

Funding Not applicable.

\section{Declarations}

Conflict of interest Not applicable.

Availability of data and material All data used in this study come from publicly available sources. 
Code availability Not applicable.

\section{References}

Adler, M. (1985). Stardom and talent. The American Economic Review, 75(1), 208-212.

Alegre, J., Mateo, S., \& Pou, L. (2013). Tourism participation and expenditure by Spanish households: The effects of the economic crisis and unemployment. Tourism Management, 39, 37-49. https://doi. org/10.1016/j.tourman.2013.04.002

Alper, N. O., \& Wassall, G. H. (1998). Artists' labor market experiences: A preliminary analysis using longitudinal data. In M. Heikkinen \& T. Koskinen (Eds.), Economics of artists and arts policy. Arts Council of Finland.

Alper, N. O., \& Wassall, G. H. (2000). More than once in a blue moon: Multiple jobholdings by American artists. Research Division Report \#40. Washington, D.C.: National Endowment for the Arts.

Alper, N. O., \& Wassall, G. H. (2006). Artists' careers and their labor markets. Handbook of the Economics of Art and Culture, 1, 813-864.

Ayllon, S., \& Nollenberger, N. (2020). The unequal opportunity for skills acquisition during the great recession in Europe. Review of Income and Wealth. https://doi.org/10.1111/roiw.12472

Baldin, A., \& Bille, T. (2021). Who is an artist? Heterogeneity and professionalism among visual artists. Journal of Cultural Economics. https://doi.org/10.1007/s10824-020-09400-5

Barr, A., \& Turner, S. (2015). Out of work and into school: Labor market policies and college enrollment during the Great Recession. Journal of Public Economics, 124, 63-73. https://doi.org/10.1016/j. [ubeco.2014.12.009

BFAMFAPhD. (2014). Artists report back: A national study on the lives of arts graduates and working artists. http://bfamfaphd.com/\#artists-report-back

Bicakova, A., Cortes, G. M., \& Mazza, J. (2020). Caught in the cycle: Economic conditions at enrollment and labor market outcomes of college graduates. IZA Discussion paper no. 13561, 1-55. https:// www.iza.org/publications/dp/13561/caught-in-the-cycle-economic-conditions-at-enrollment-andlabor-market-outcomes-of-college-graduates

Bille, T., Fjællegaard, C. B., Frey, B. S., \& Steiner, L. (2013). Happiness in the arts-International evidence on artists' job satisfaction. Economics Letters, 121(1), 15-18. https://doi.org/10.1016/j.econl et.2013.06.016

Bille, T., \& Jensen, S. (2018). Artistic education matters: Survival in the arts occupations. Journal of Cultural Economics, 42, 23-43. https://doi.org/10.1007/s10824-016-9278-5

Carnevale, A. P., Cheah, B., \& Strohl, J. (2012). Hard times: College majors, unemployment, and earnings. Georgetown University Center for Education and the Workforce. https://cew.georgetown.edu/ cew-reports/hard-times-2012/\#: : text=Hard\%20Times\%3A\%20College\%20Majors\%2C\%20Une mployment $\% 2$ C\%20and\%20Earnings \%20argues\%20that,better\%20employment $\% 20$ prospects $\%$ 20than\%20others

Cozzolino, E., Smith, C., \& Crosnoe, R. L. (2018). Family-related disparities in college enrollment across the great recession. Sociological Perspectives, 61(5), 689-710. https://doi.org/10.1177/0731121418 760542

Cunningham, E. (2018). Great recession, great recovery? Trends from the current population survey. Monthly Labor Review, U.S. Bureau of Labor Statistics. https://doi.org/10.21916/mlr.2018.10

Eadington, W. R. (2011). After the great recession: The future of casino gaming in America and Europe. Economic Affairs (Harlow), 31(1), 27-33. https://doi.org/10.1111/j.1468-0270.2010.02044.x

Frank, R. H., \& Cook, P. J. (1995). The winner-take-all society. The Free Press.

Frenette, A., \& Dowd, T. J. (2018). Who stays and who leaves? Arts education and the career trajectories of arts alumni in the United States. National Endowment for the Arts Working Paper 1-67. https:// www.arts.gov/sites/default/files/Research-Art-Works-ASU2.pdf

Gao, L., \& Kim, H. (2018). Consumer spending on entertainment and the Great Recession. Leisure/Loisir, 42(3), 281-300. https://doi.org/10.1080/14927713.2018.1535278

Gerber, A., \& Childress, C. (2017). The economic world obverse: Freedom through markets after arts education. American Behavioral Scientist, 61, 1532-1554. https://doi.org/10.1177/0002764217 734275 
Ghayad, R. (2013). The Jobless Trap. Working paper. https://citeseerx.ist.psu.edu/viewdoc/download? doi=10.1.1.692.6736\&rep=rep1\&type $=$ pdf

Grant, D. (2017). Grades, talent and art college admissions. Inside Higher Ed. https://www.insidehigh ered.com/admissions/article/2017/06/12/art-colleges-consider-role-traditional-academic-measu res-admissions\#: :text=Most $\% 20$ art $\% 20$ college $\% 20$ admissions $\% 20$ offices, a $\% 20$ high $\% 20$ school $\%$ 20art\%20teacher

Hampf, F., Piopiunik, M., \& Wiederhold, S. (2020). The effects of graduating from high school in a recession: College investments, skill formation, and labor-market outcomes. CESifo working paper no. 8252, 1-57. https://www.cesifo.org/en/publikationen/2020/working-paper/effects-graduatinghigh-school-recession-college-investments-skill

Kisswani, K. (2008). Did the great depression affect education attainment in the US? Economics Bulletin, 9(30), 1-10.

Kondo, A. (2015). Differential effects of graduating during a recession across gender and race. IZA Journal of Labor Economics, 4(23), 1-23. https://doi.org/10.1186/s40172-015-0040-6

Lena, J. C., Gaskill, S., Houghton, R. F., Lambert, A. D., Miller, A. L. \& Tepper, S. J. (2014). Making it work: The education and employment of recent arts graduates, SNAAP annual report 2014. Bloomington, IN: Center for Postsecondary Research, Indiana University, School of Education. http:// snaap.indiana.edu/pdf/2014/SNAAP_AR_2014.pdf

Lindemann, D. J., Tepper, S. J., Gaskill, S., Jones, S. D., Kuh, G. D., Lambert, A. D., Lena, J., Miller, A. L., Park, K., Rudolph, E. B., \& Vanderwerp, L. (2012). Painting with broader strokes: Reassessing the Value of an arts education. Bloomington, IN: Indiana University and Vanderbilt University, Strategic National Arts Alumni Project. http://snaap.indiana.edu/pdf/SNAAP_Special\%20Report_1.pdf

Menger, P. M. (2006). Artistic labor markets: Contingent work, excess supply and occupational risk management. Handbook of the Economics of Art and Culture, 1, 765-811.

Miringoff, M., \& Opdycke, S. (2010). The arts in a time of recession. The International Journal of the Arts in Society, 4(5), 1-32.

Modestino, A. S., Shoag, D., \& Ballance, J. (2020). Upskilling: Do employers demand greater skill when workers are plentiful? The Review of Economics and Statistics, 102(4), 793-805. https://doi.org/10. 1162/rest_a_00835

Nicholas, B. (2009). Artists in a year of recession: Impact on JOBS in 2008. NEA Research Note \#97, 1-10. https://www.arts.gov/impact/research/publications/artists-year-recession-impact-jobs-2008

Nicholas, B. (2010). Artist unemployment rates for 2008 and 2009. NEA Research Bulletin, 1-6. https:// www.arts.gov/sites/default/files/97-update.pdf

Oreopoulos, P., von Wachter, T., \& Heisz, A. (2012). The short- and long-term career effects of graduating in a recession. American Economic Journal: Applied Economics, 4(1), 1-29. https://doi.org/10. 1257/app.4.1.1

Paulsen, R., Alper, N., \& Wassall, G. (2021). Arts majors as entrepreneurs and innovators. Small Business Economics, 57, 639-652. https://doi.org/10.1007/s11187-020-00416-X

Ramos, C., \& Baugher, D. (2013). The impact of the great recession of 2007 to 2009 on perception of the value of arts education and the ability to gain funding in New York City. American Journal of Arts Management, 1(1), 1-11.

Rengers, M. (2002). Economic lives of artists: Studies into careers and the labour market in the cultural sector. Utrecht: Utrecht University, Interuniversity Center for Social Science Theory and Methodology. https://dspace.library.uu.nl/handle/1874/815

Ritchie, J. R. B., Amaya Molinar, C. M., \& Frechtling, D. C. (2010). Impacts of the world recession and economic crisis on tourism: North America. Journal of Travel Research, 49(1), 5-15. https://doi. org/10.1177/0047287509353193

Rosen, S. (1981). The economics of superstars. The American Economic Review, 71(5), 845-858.

Rothstein, J. (2020). The lost generation? Labor market outcomes for post great recession entrants. NBER working paper no. 27516 (pp. 1-49). https://doi.org/10.3386/w27516

Ruggles, S., Flood, S., Foster, S., Goeken, R., Pacas, J., Schouweiler, M \& Sobek, M. (2020). IPUMS USA: Version 10.0 [dataset]. Minneapolis, MN. https://doi.org/10.18128/D010.V10.0

Steiner, L., \& Schneider, L. (2013). The happy artist: An empirical application of the work-preference model. Journal of Cultural Economics, 37, 225-246. https://doi.org/10.1007/s10824-012-9179-1

Throsby, D. (1986). Occupational and employment characteristics of artists. Policy and Planning Division, Australia Council.

Throsby, D. (1996). Disaggregated earnings functions for artists. In V. Ginsburgh \& P.-M. Menger (Eds.), Economics of the arts: Selected essays (pp. 331-346). Kluwer Academic Publishers. 
Thosby, D. \& Petetskaya, K. (2017). Marking art work: An economic study of professional artists in Australia. Australia Council for the Arts. https:/www.australiacouncil.gov.au/research/making-art-work/

Wassall, G. \& Alper, N. (2018). The importance of a college major in the arts to artistic success. National endowment for the arts working paper. https://www.arts.gov/sites/default/files/Research-Art-WorksNortheastern-rev.pdf

Woronkowicz, J. (2015). Artists, employment and the great recession: A cross-sectional analysis using US current population survey data. Cultural Trends, 24(2), 154-164. https://doi.org/10.1080/09548 963.2015.103148

Woronkowicz, J., \& Noonan, D. S. (2019). Who goes freelance? The determinants of self-employment for artists. Entrepreneurship Theory and Practice, 43(4), 651-672. https://doi.org/10.1177/10422 58717728067

Zafar, B. (2012). Double majors: One for me, one for the parents? Economic Inquiry, 50(2), 287-308. https://doi.org/10.1111/j.1465-7295.2011.00403.x

Publisher's Note Springer Nature remains neutral with regard to jurisdictional claims in published maps and institutional affiliations. 